\title{
Contact Sensitization to the Allergens of European Baseline Series in Patients With Chronic Leg Ulcers
}

\author{
Aistė Beliauskiené ${ }^{1}$, Skaidra Valiukevičiené ${ }^{1}$, Brigita Šitkauskiené2, \\ Axel Schnuch ${ }^{3}$, Wolfgang Uter ${ }^{4}$ \\ ${ }^{1}$ Department of Skin and Venereal Diseases, Medical Academy, Lithuanian University of Health Sciences, Lithuania, \\ ${ }^{2}$ Department of Pulmonology and Immunology, Medical Academy, Lithuanian University of Health Sciences, Lithuania, \\ ${ }^{3}$ Information Network of Departments of Dermatology (IVDK), University of Göttingen, Germany, \\ ${ }^{4}$ Department of Medical Informatics, Biometry and Epidemiology, University of Erlangen-Nürnberg, Germany
}

Key words: allergic contact dermatitis; benzocaine; lanolin alcohol; leg ulcers; p-phenylenediamine; patch tests.

Summary. Background and Objective. The pattern of contact sensitization among patients with chronic leg ulcers depends on the local practice of wound treatment along with demographic and clinical confounders. The study was aimed at revealing the associations between chronic leg ulcers and contact sensitization.

Material and Methods. Between 2006 and 2008, 35 patients with chronic leg ulcers and surrounding dermatitis and 59 patients with contact dermatitis of the lower leg or foot were prospectively recruited at the Department of Skin and Venereal Diseases, Lithuanian University of Health Sciences. Demographic and clinical data were collected in accordance with the "minimal data set" of the European Surveillance System on Contact Allergy. Patch testing was performed with the allergens of the European baseline series.

Results. At least one positive patch test reaction was found in 28 (80\%) of the patients with chronic leg ulcers and in $24(41 \%)$ of the patients with dermatitis of the lower leg or foot $(P<0.001)$. Sensitization to some of the most common allergens, namely colophony, Myroxylon pereirae resin, and methyldibromo glutaronitrile, was prevalent in both the groups of patients, whereas sensitization to benzocaine, p-phenylenediamine, and lanolin alcohol was associated with the presence of chronic leg ulcers. Benzocaine was found to be the leading allergen among patients with chronic leg ulcers (positive patch test reactions in $34.4 \%$ of the patients).

Conclusions. Contact sensitization to benzocaine, p-phenylenediamine, and lanolin was found to be associated with the presence of chronic leg ulcers.

\section{Introduction}

Chronic leg ulcers (CLU) are a common disease affecting $0.12 \%-1.1 \%$ of the population worldwide (1). Long duration of the illness, local inflammatory milieu, damage to the skin barrier, and use of many topical medicaments, together with occlusive bandages promoting skin penetration, frequently lead to contact sensitization and, consequently, to allergic contact dermatitis (2-8). Allergic contact dermatitis of the surrounding skin, in turn, may impede the healing of ulcers and restrict the choice of treatment options. Furthermore, in sensitized patients with leg ulcers, allergic contact dermatitis may develop at sites other than legs due to direct allergen exposure, dissemination from the ulcer site, or systemic spread (9).

The spectrum of the most frequent contact allergens among patients with CLU mainly depends on the local practice of wound treatment. Moreover, the sensitization to contact allergens is strongly influenced by older age of patients with leg ulcers as well as the site of dermatitis $(10,11)$. As a result, time and regional trends in the prevalence of sensitization to important contact allergens among patients with CLU have been observed (2-8). The present study was aimed at revealing the associations between chronic leg ulcers and contact sensitization and determining the most common allergens in the patients with CLU and surrounding dermatitis.

\section{Material and Methods}

Study Population. Between April 2006 and October 2008, 35 patients with CLU and surrounding dermatitis in the Department of Skin and Venereal Diseases, Lithuanian University of Health Sciences,
Correspondence to A. Beliauskienė, Department of Skin and Venereal Diseases, Medical Academy, Lithuanian University of Health Sciences, Eivenių 2, 50028 Kaunas, Lithuania E-mail: aiste@asb.lt
Adresas susirašinėti: A. Beliauskienè, LSMU MA Odos ir venerinių ligų klinika, Eivenių 2, 50028 Kaunas El. paštas: aiste@asb.lt 
were prospectively recruited. CLU was diagnosed based on the finding a wound on a patient's foot or leg below the knee that had persisted longer than 6 weeks according to the previously described criteria (12). Surrounding dermatitis was diagnosed when 2 or more of its symptoms - erythema, erythematous papules, vesicles, scaling, fissures, and lichenification (13) - were detected on the skin surrounding the ulcer.

To assess the impact of CLU on contact sensitization, the group of patients with CLU was compared with that of patients with dermatitis at the same localization but without ulcers. A total of 59 adult patients with dermatitis of the lower leg or foot, aged 18 and more, were recruited for patch testing during the same period.

Demographic and clinical data on the surveyed patients were collected in accordance with the "minimal dataset" of the European Surveillance System on Contact Allergy (ESSCA) (14). Concomitant atopic dermatitis (past or current) was determined from medical documentation and/or by clinical examination at the time of patch testing using the standard criteria by Hanifin and Rajka (15). Occupational causation or aggravation of dermatitis was determined according to the criteria proposed by Mathias (16). The study was approved by the regional Bioethics Committee. Written informed consent was obtained from all the participating patients before the study.

Patch Testing. Patch testing was performed following the guidelines of the International Contact Dermatitis Research Group (17). In the study, the allergens of the European baseline series proposed by the European Society of Contact Dermatitis in 2008, except for tixocortol-21-pivalate, were used (18). All allergens were kindly provided by Trolab Hermal, Reinbek, Germany. Twenty patients who had been treated with modern wound dressings underwent patch testing with three commercial products, namely Granuflex ${ }^{\circledR}$ dressing (ConvaTec), Aquacel ${ }^{\circledR}$ Ag dressing (ConvaTec), and Mepilex ${ }^{\circledR}$ dressing (Molnlycke Health Care). The allergens were applied to the upper back skin for 48 hours using Finn Chambers on Scanpor (Epitest Ltd Oy, Tuusula, Finland). The wound dressings were applied "as is" using an adhesive tape. Readings were performed on days 2 and 3. Positive patch tests were defined morphologically as reactions + (palpable erythema), ++ (strong edematous or vesicular reaction), or +++ (coalescing vesicles) on day 3 .

Statistical Analysis. For the acquisition, processing, and statistical analysis of data, the software WinAlldat/Essca (12), SAS version 9.1 (The SAS Institute Inc., Cary, NC, USA), and SPSS version 13.0 (Chicago, IL, USA) were used. The proportions of positive patch test reactions are provided with 95\% confidence intervals (95\% CI). Comparison of the proportions observed in two independent groups (CLU and contact dermatitis of the lower leg or foot) was made using the chi-square test or Fisher exact test, in case of expected cell frequencies below 5 (13). $P<0.05$ indicated statistical significance. In view of the exploratory nature of analyses, no alpha adjustment techniques were employed. To evaluate the concordance of positive patch test results to different allergens, simple Cohen kappa with 95\% CI was calculated.

\section{Results}

A total of 35 patients with CLU and surrounding dermatitis as well as 59 patients with contact dermatitis of the lower leg or foot were examined. Descriptive characteristics of the studied groups are presented in Table 1 . The patients with CLU ranged in age from 30 to 86 years (median, 68 years; interquartile range, $60-79$ years). The patients with dermatitis of the lower leg or foot and without ulcers were significantly younger $(P=0.027)$, with their age ranging from 18 to 87 years (median, 56 years; interquartile range, $46-67$ years). The mean duration of leg ulcers was 56 months (median, 24 months; range, 2-336 months).

At least one positive patch test reaction to the allergens of the European baseline series was documented in $28(80 \%)$ of the patients with CLU and in $24(41 \%)$ of the patients with dermatitis of the lower leg or foot $(P<0.001)$. Three or more positive patch test reactions were found in $9(26 \%)$ of the patients with CLU and in $5(8.5 \%)$ of the patients with dermatitis of the lower leg or foot $(P<0.035)$. The frequencies of positive patch test reactions to individual allergens of the European baseline series in both the groups of patients are presented in Table 2. Cross-

Table 1. Descriptive Characteristics of Patients With Chronic Leg Ulcers and Surrounding Dermatitis and Patients With Contact Dermatitis of the Lower Leg or Foot

\begin{tabular}{|c|c|c|c|}
\hline Characteristic & $\begin{array}{l}\text { Patients with Chronic Leg Ulcers and } \\
\text { Surrounding Dermatitis }(\mathrm{N}=35)\end{array}$ & $\begin{array}{c}\text { Patients With Dermatitis } \\
\text { of the Lower Leg or Foot }(\mathrm{N}=59)\end{array}$ & $P$ Value \\
\hline Male, n (\%) & $14(40)$ & $28(47.5)$ & 0.48 \\
\hline Occupational dermatitis, n (\%) & $1(2.9)$ & $8(13.6)$ & 0.15 \\
\hline Atopic dermatitis, n (\%) & $1(2.9)$ & $6(10.2)$ & 0.31 \\
\hline Aged 40 years and more, $\mathrm{n}(\%)$ & $34(97.1)$ & $48(81.4)$ & 0.027 \\
\hline
\end{tabular}


Table 2. Patch Test Results With the European Baseline Series in Patients With Chronic Leg Ulcers and Surrounding Dermatitis and Patients With Contact Dermatitis of the Lower Leg or Foot

\begin{tabular}{|c|c|c|c|c|c|}
\hline \multirow{2}{*}{ Allergen and Concentration (\%) } & \multicolumn{2}{|c|}{$\begin{array}{c}\text { Patients With Chronic Leg } \\
\text { Ulcers and Surrounding } \\
\text { Dermatitis }(\mathrm{N}=35)\end{array}$} & \multicolumn{2}{|c|}{$\begin{array}{c}\text { Patients With Contact } \\
\text { Dermatitis of the Lower Leg } \\
\text { or Foot }(\mathrm{N}=59)\end{array}$} & \multirow{2}{*}{$\begin{array}{c}P \\
\text { Value }\end{array}$} \\
\hline & $\begin{array}{l}\text { No. of } \\
\text { Positive } \\
\text { Reactions }\end{array}$ & $\begin{array}{l}\% \text { of Positive } \\
\text { Reactions } \\
(95 \% \mathrm{CI})\end{array}$ & $\begin{array}{l}\text { No. of } \\
\text { Positive } \\
\text { Reactions }\end{array}$ & $\begin{array}{l}\% \text { of Positive } \\
\text { Reactions } \\
(95 \% \mathrm{CI})\end{array}$ & \\
\hline Benzocaine (5.0) & 12 & $34.3(18.6-50)$ & 1 & $1.7(0-5)$ & $<0.0001$ \\
\hline Colophonium (20) & 7 & $20(6.8-33.3)$ & 8 & $13.6(4.8-22.3)$ & NS \\
\hline Myroxylon pereirae resin (25) & 7 & $20(6.8-33.3)$ & 5 & $8.5(1.4-15.6)$ & NS \\
\hline p-Phenylenediamine (1.0) & 7 & $20(6.8-33.3)$ & 1 & $1.7(0-5)$ & 0.002 \\
\hline Lanolin alcohol (30) & 6 & $17.1(4.7-29.6)$ & 2 & $3.4(0-8)$ & 0.02 \\
\hline 5-Chloro-7-iodo-8-quinolinol (5.0) & 3 & $8.6(0-17.8)$ & 0 & 0 & NS \\
\hline Methyldibromo glutaronitrile (0.3) & 3 & $8.6(0-17.8)$ & 4 & $6.8(0.4-13.2)$ & NS \\
\hline Fragrance mix II (14) & 2 & $5.7(0-13.4)$ & 2 & $3.4(0-8)$ & NS \\
\hline Nickel sulfate (5.0) & 2 & $5.7(0-13.4)$ & 1 & $1.7(0-5)$ & NS \\
\hline Paraben mix (16) & 2 & $5.7(0-13.4)$ & 2 & $3.4(0-8)$ & NS \\
\hline Sesquiterpene lactone $\operatorname{mix}(0.1)$ & 2 & $5.7(0-13.4)$ & 0 & 0 & NS \\
\hline Budesonide (0.01) & 1 & $2.9(0-8.4)$ & 0 & 0 & NS \\
\hline Formaldehyde* (1.0) & 1 & $2.9(0-8.4)$ & 2 & $3.4(0-8)$ & NS \\
\hline Fragrance mix I (8.0) & 1 & $2.9(0-8.4)$ & 1 & $1.7(0-5)$ & NS \\
\hline$N$-isopropyl- $N$ '-phenyl-p-phenylene diamine $(0.10)$ & 1 & $2.9(0-8.4)$ & 0 & 0 & NS \\
\hline Neomycin sulfate $(20)$ & 1 & $2.9(0-8.4)$ & 2 & $3.4(0-8)$ & NS \\
\hline 4-tert-Butylphenol formaldehyde resin (1.00) & 1 & $2.9(0-8.4)$ & 0 & 0 & NS \\
\hline Primin $(0.01)$ & 1 & $2.9(0-8.4)$ & 0 & 0 & NS \\
\hline Methylchloroisothiazolinone/Methylisothiazolinone* $(0.01)$ & 1 & $2.9(0-8.4)$ & 3 & $5.1(0-10.7)$ & NS \\
\hline Cobalt (II) chloride (1.0) & 0 & 0 & 1 & $1.7(0-5)$ & NS \\
\hline Epoxy resin (1.0) & 0 & 0 & 1 & $1.7(0-5)$ & NS \\
\hline Hydroxyisohexyl 3-cyclohexene carboxaldehyde (5.0) & 0 & 0 & 0 & 0 & $\ldots$ \\
\hline 2-Mercaptobenzothiazole (2.0) & 0 & 0 & 0 & 0 & $\ldots$ \\
\hline Mercapto mix (only CBS, MBTS, MOR) (1.0) & 0 & 0 & 0 & 0 & $\ldots$ \\
\hline Potassium dichromate $(0.5)$ & 0 & 0 & 5 & $8.5(1.4-15.6)$ & NS \\
\hline Quaternium-15 (1.0) & 0 & 0 & 1 & $1.7(0-5)$ & NS \\
\hline Thiuram mix (1.0) & 0 & 0 & 0 & 0 & $\ldots$ \\
\hline
\end{tabular}

All allergens in petrolatum, except where otherwise indicated: *water. NS, not significant. Ellipses indicate $P$ value not computed.

Table 3. Cross-Reactivity Between Benzocaine and p-Phenylenediamine (PPD) in Patients With Chronic Leg Ulcers

\begin{tabular}{lccc}
\hline & $\begin{array}{c}\text { PPD-Positive } \\
\text { Patients }\end{array}$ & $\begin{array}{c}\text { PPD-Negative } \\
\text { Patients }\end{array}$ & Total \\
\hline $\begin{array}{l}\text { Benzocaine- } \\
\text { positive patients }\end{array}$ & 6 & 6 & 12 \\
\hline $\begin{array}{l}\text { Benzocaine- } \\
\text { negative patients }\end{array}$ & 1 & 22 & 23 \\
\hline Total & 7 & 28 & 35 \\
\hline
\end{tabular}

reactivity between benzocaine and p-phenylenediamine (PPD) is shown in Table 3; concordance of positive vs. negative reactions was quite marked (Cohen kappa, 0.51; 95\% CI, 0.21 to 0.81 ). Of the 20 patients with CLU tested with wound dressings, 5 patients $(25 \% ; 95 \%$, CI $6 \%$ to $44 \%)$ showed positive patch test reactions to Granuflex, whereas there were no positive reactions to Mepilex and Aquacel Ag.

\section{Discussion}

In line with previous research findings in the area, this study confirms the high prevalence of contact allergy among patients with CLU. Patch testing of all patients with leg ulcers, independently of the pres- ence of dermatitis of the surrounding skin, has been widely recommended due to the high proportion of patch test positivity $(57 \%-73 \%)$ recorded even in the absence of clinical signs of contact dermatitis around the ulcers $(4,7)$. However, clinical relevance of positive patch test reactions in these cases often remains questionable. To enhance the relevance of its findings, only patients with dermatitis surrounding the ulcers were included in this study. Despite the relatively small sample size, some important features of contact sensitization among patients with leg ulcers were revealed.

It is common knowledge that contact sensitization is strongly influenced by age in general and dermatitis of the lower leg in particular $(10,11)$. In Lithuania, a significantly higher prevalence of sensitization to Myroxylon pereirae resin, colophony, fragrance mix I, lanolin alcohol, sesquiterpene lactone mix, and primin was detected in consecutively patch tested patients aged 40 years and more (19). Therefore, the high frequency of contact allergy to Myroxylon pereirae resin, colophony, and lanolin alcohol found in the present study among patients with CLU can be in part attributable to their older age.

To evaluate the impact of the presenting site of 
dermatitis on sensitization to contact allergens, the group of patients with CLU was compared with that of patients with contact dermatitis of the lower leg or foot. Sensitization to some of the most important allergens, namely colophony, Myroxylon pereirae resin, and methyldibromo glutaronitrile, was prevalent in both groups of patients, whereas sensitization to benzocaine, PPD, and lanolin alcohol was associated with the presence of CLU. To reveal the impact of potential demographic and clinical confounders, the proportion of variables according to the MOAHLFA index (Male sex, Occupational causation, Atopic dermatitis, primary Hand, Leg, Face dermatitis, Age 40 years and above) has to be presented for meaningful interpretation of patch test results (20). It is evident that among patients with leg dermatitis, the subgroup of patients with CLU may significantly influence the results, while being not indicated in the index.

Benzocaine, a local anesthetic of $p$-aminobenzoic acid ester group, was found to be the leading allergen, with more than one-third of patients with CLU displaying sensitization to it. Generally, anesthetics are not recommended for local ulcer treatment (21). Moreover, pain may indicate inappropriate ulcer management, such as improper application of compression therapy and drying or infection of the ulcer. In such cases, pain relief delays urgent changes in treatment and, subsequently, healing. The results of this study suggest a notably higher prevalence of contact allergy to benzocaine than $1.2 \%-4 \%$ found in other studies of patients with leg ulcers $(3,4,7,8)$. This potentially implies malpractice in ulcer treatment, when despite the broad choice of modern wound dressings, the use of topical medicaments containing anesthetics is still abundant. Benzocaine and other anesthetics of ester group (procaine, tetracaine) are considered to be more potent sensitizers than the anesthetics of amide group (22). Hence, if local anesthetics are urgent, amide derivatives should be preferred.

A strong influence of the presence of CLU on contact sensitization to PPD was observed. Oxidative hair dyes and dark henna temporary "tattoos," the most prominent causes of PPD sensitization, are not relevant in the group of patients. However, a positive patch test reaction to PPD may also occur as a result of cross-sensitization to other allergens: benzocaine, sulfonamides, $N$-isopropyl- $N$ '-phenyl$p$-phenylenediamine, and textile dyes (23). From the allergens listed above, $N$-isopropyl- $N$ '-phenyl$p$-phenylenediamine was found to be an extremely rare sensitizer in Lithuania (19). Therefore, crosssensitization to topically used benzocaine, sulfonamides (such as silver sulfadiazine widely used for wound treatment), and textile dyes is likely to be responsible for the observed sensitization to PPD. In the present study, $50 \%$ of the patients with CLU and positive patch test reactions to benzocaine positively reacted to PPD (Table 3), nearly the same as $49.3 \%$ found in a large German study (24).

The high prevalence of contact allergy to colophony was found in both patients with CLU and patients with dermatitis of the lower leg or foot. Yet, the sources of the allergen in the two groups were probably different. Colophony is a widespread, naturally occurring material obtained from the resin of Pinaceae trees. Unmodified colophony or its chemically modified forms used in cosmetic products (depilatories), glues (shoes), varnishes, and adhesives (adhesive tapes) may cause primary leg dermatitis. In patients with leg ulcers, modified colophonium derivates are considered the most common cause of allergic contact dermatitis to hydrocolloid dressings. Unfortunately, the patch test with unmodified colophony included in the baseline series often fails to detect contact allergy to colophony derivates (25). However, in the present study, 3 of the 5 patients with positive patch test reactions to Granuflex hydrocolloid dressing, which contains modified colophony according to the manufacturer, also showed positive reactions to colophony. This shows that sensitization to modified colophony can sometimes be detected with the preparations of baseline series allergens. Thus, although providing optimal conditions for ulcer healing, modern wound dressings may sensitize and cause allergic contact dermatitis. In such cases, if possible, other treatment modalities decreasing the use of topical medicaments, such as skin grafting (26), should be applied instead.

Contact sensitization to lanolin alcohol was found to be more frequent among patients with CLU than among the patients with contact dermatitis of the lower leg or foot. Other studies involving the patients with leg ulcers similarly reported a high prevalence of sensitization to this allergen, ranging from $6.8 \%$ in Singapore to $30.0 \%$ in Poland (3, 4, $7,8)$. It is noteworthy that these results were influenced by the older age of patients with leg ulcers as the prevalence of sensitization to lanolin increases with age $(19,27)$. Nevertheless, the findings confirm the well-documented potential of lanolin to induce frequently sensitization and elicit allergic contact dermatitis on damaged skin, while being a very rare sensitizer and cause of dermatitis when used on healthy skin (28). It is therefore highly advisable to avoid the application of products containing lanolin on damaged skin.

\section{Conclusions}

In this study, significant differences in the fre- 
quencies of sensitization to some allergens of the European baseline series were found comparing the patients with chronic leg ulcers and those with dermatitis of the lower leg or foot. In the patients with chronic leg ulcers, benzocaine was found to be the leading allergen, which attests to the vicious use of topical anesthetics.

\section{Acknowledgments}

The study was financially supported by the European Surveillance System on Contact Allergies and the Hermal Kurt Herrmann GmbH \& Co OHG.

\section{Statement of Conflict of Interest}

The authors state no conflict of interest.

\title{
Lètinėmis kojų opomis sergančiųjų įsijautrinimas Europos pagrindinio rinkinio kontaktiniams alergenams
}

\author{
Aistè Beliauskiené ${ }^{1}$, Skaidra Valiukevičiené ${ }^{1}$, Brigita Šitkauskienè ${ }^{2}$, \\ Axel Schnuch ${ }^{3}$, Wolfgang Uter ${ }^{4}$ \\ ${ }^{1}$ Lietuvos sveikatos moksly universiteto Medicinos akademijos Odos ir veneriniu ligu klinika, Lietuva, \\ ${ }^{2}$ Lietuvos sveikatos moksly universiteto Medicinos akademijos Pulmonologijos ir imunologijos klinika, Lietuva, \\ ${ }^{3}$ Giotingeno universiteto Dermatologijos kliniku informacinis tinklas, Vokietija, \\ ${ }^{4}$ Erlangeno-Niurnbergo universiteto Medicinines informatikos, biometrijos ir epidemiologijos departamentas, Vokietija
}

Raktažodžiai: alerginis kontaktinis dermatitas, benzokainas, lanolinas, kojų opos, parafenilendiaminas, alergenų lopo mėginiai.

Santrauka. Tyrimo tikslas. Kojų opomis sergančiųu įsijautrinimas kontaktiniams alergenams priklauso nuo žaizdų gydymo praktikos, pacientų sociodemografinių veiksnių bei klinikos ypatumų. Tyrimo tikslas. Nustatyti lètinių kojų opu ir įsijautrinimo kontaktiniams alergenams sąsajas.

Tiriamuju kontingentas ir tyrimo metodai. I tyrimą įtraukti 2006-2008 m. Lietuvos sveikatos mokslu universiteto Odos ir venerinių ligų klinikos pacientai, sirgę lètinėmis kojų opomis bei dermatitu $(n=35)$, ir blauzdų arba pėdų dermatitu sirgę pacientai (lyginamoji grupé, $n=59$ ). Demografiniai ir klinikiniai tiriamujų duomenys surinkti pagal Europos kontaktinès alergijos stebėsenos tyrimo protokolą. Tiriamiesiems atlikti alergenų lopo méginiai naudojant Europos pagrindinio rinkinio kontaktinius alergenus.

Rezultatai. İsijautrinimas kontaktiniams alergenams nustatytas 28 (80 proc.) sergantiesiems lètinėmis kojų opomis ir 24 (41 proc.) - sergantiesiems blauzdų arba pẻdų dermatitu $(\mathrm{p}<0,001)$. Myroxylon Pereirae derva (Peru balzamas) ir metildibromogliutaronitrilas buvo dažni kontaktiniai alergenai abiejose tiriamųų grupèse, o įsijautrinimas benzokainui, parafenilendiaminui ir vilnos alkoholiams (lanolinui) dažniau nustatytas sergantiesiems lètinèmis kojų opomis. Benzokainas buvo dažniausias kontaktinis alergenas sergantiesiems lètinèmis kojų opomis (34,3 proc. teigiamų lopo mėginių reakcijų).

Išvados. İsijautrinimas benzokainui, parafenilendiaminui ir vilnos alkoholiams (lanolinui) yra susijęs su lètinèmis kojų opomis.

\section{References}

1. Graham ID, Harrison MB, Nelson EA, Lorimer K, Fisher A. Prevalence of lower-limb ulceration: a systematic review of prevalence studies. Adv Skin Wound Care 2003;16:305-16.

2. Tavadia S, Bianchi J, Dawe RS, McEvoy M, Wiggins E, Hamill E, et al. Allergic contact dermatitis in venous leg ulcer patients. Contact Dermatitis 2003;48:261-5.

3. Machet L, Couhe C, Perrinaud A, Hoarau C, Lorette G, Vaillant L. A high prevalence of sensitization still persists in leg ulcer patients: a retrospective series of 106 patients tested between 2001 and 2002 and a meta-analysis of 19752003 data. Br J Dermatol 2004;150:929-35.

4. Saap L, Fahim S, Arsenault E, Pratt M, Pierscianowski T, Falanga V, et al. Contact sensitivity in patients with leg ulcerations: a North American study. Arch Dermatol 2004; 140:1241-6.

5. Lim KS, Tang MB, Goon AT, Leow YH. Contact sensitization in patients with chronic venous leg ulcers in Singapore. Contact Dermatitis 2007;56:94-8.

6. Jankicevic J, Vesic S, Vukicevic J, Gajic M, Adamic M, Pavlovic MD. Contact sensitivity in patients with venous leg ulcers in Serbia: comparison with contact dermatitis patients and relationship to ulcer duration. Contact Dermatitis 2008;58:32-6.

7. Barbaud A, Collet E, Le Coz CJ, Meaume S, Gillois P. Contact allergy in chronic leg ulcers: results of a multicentre study carried out in 423 patients and proposal for an updated series of patch tests. Contact Dermatitis 2009;60:279-87.

8. Zmudzinska M, Czarnecka-Operacz M, Silny W, Kramer L. Contact allergy in patients with chronic venous leg ulcers - possible role of chronic venous insufficiency. Contact Dermatitis 2006;54:100-5.

9. Lachapelle JM. The spectrum of diseases in which patch testing is recommended. In: Lachapelle JM, Maibach HI, editors. Patch testing and prick testing. 2nd ed. Berlin Heidelberg: Springer-Verlag; 2009. p. 7-32.

10. Schnuch A. PAFS: population-adjusted frequency of sensitization. (I) Influence of sex and age. Contact Dermatitis 1996;34:377-82.

11. Uter W, Geier J, Pfahlberg A, Effendy I. The spectrum of contact allergy in elderly patients with and without lower leg dermatitis. Dermatology 2002;204:266-72. 
12. Lin P, Phillips T. Ulcers. In: Bolognia J, Jorizzo J, Rapini R, Horn T, Mancini A, Mascaro J, et al., editors. Dermatology. New York: Mosby; 2008. p. 1631-49.

13. Veien NK. General aspects. In: Frosch P, Menne T, Lepoittevin JP, editors. Contact dermatitis. Berlin Heidelberg: Springer-Verlag; 2006. p. 201-54.

14. Proposed contents and categories of the ESSCA system ("minimal dataset"). Available from: URL: http://www.ivdk. gwdg.de/essca/doc

15. Hanifin JM, Rajka G. Diagnostic features of atopic dermatitis. Acta Derm Venereol 1980;92:44-7.

16. Mathias CG. Contact dermatitis and workers' compensation: criteria for establishing occupational causation and aggravation. J Am Acad Dermatol 1989;20:842-8.

17. Lachapelle JM, Maibach HI. Patch testing methodology. In: Lachapelle JM, Maibach HI, editors. Patch testing and prick testing. Berlin Heidelberg: Springer-Verlag; 2009. p. 33-70.

18. Bruze M, Andersen KE, Goossens A. Recommendation to include fragrance mix 2 and hydroxyisohexyl 3-cyclohexene carboxaldehyde (Lyral) in the European baseline patch test series. Contact Dermatitis 2008;58:129-33.

19. Beliauskienè A, Valiukevičienè S, Uter W, Schnuch A. The European baseline series in Lithuania: results of patch testing in consecutive adult patients. J Eur Acad Dermatol Venereol 2011;25:59-63.

20. Uter W, Schnuch A, Gefeller O. Guidelines for the descriptive presentation and statistical analysis of contact allergy data. Contact Dermatitis 2004;51:47-56.

Received 2 May 2011, accepted 30 September 2011 Straipsnis gautas 201105 02, priimtas 20110930
21. Triponis V. Treatment algorithm of venous ulcers. Lithuanian Surgery 2006;4:226-31.

22. Brandao FM, Goossens A, Tosti A. Topical drugs. In: Frosch P, Menne T, Lepoittevin JP, editors. Contact dermatitis. 4th ed. Berlin Heidelberg: Springer Verlag; 2006. p. 623-52.

23. Thyssen JP, Andersen KE, Bruze M, Diepgen T, GimenezArnau AM, Goncalo M, et al. p-Phenylenediamine sensitization is more prevalent in central and southern European patch test centres than in Scandinavian: results from a multicentre study. Contact Dermatitis 2009;60:314-9.

24. Uter W, Lessmann H, Geier J, Becker D, Fuchs T, Richter G. Die Epikutantestung mit "Parastoffen". (Patch testing with para amino compounds.) Dermatol Beruf Umwelt 2002;50:97-104.

25. Pereira TM, Flour M, Goossens A. Allergic contact dermatitis from modified colophonium in wound dressings. Contact Dermatitis 2007;56:5-9.

26. Jankūnas V, Bagdonas R, Samsanavičius D, Rimdeika R. The influence of surgical treatment for chronic leg ulcers on the quality dynamics of the patient's life. Acta Chir Belg 2007; 107:386-96.

27. Wakelin SH, Smith H, White IR, Rycroft RJ, McFadden JP. A retrospective analysis of contact allergy to lanolin. Br J Dermatol 2001;145:28-31.

28. Andersen KE, White IR, Goossens A. Allergens from the standard series. In: Frosch PJ, Menne T, Lepoittevin JP, editors. Contact dermatitis. 4th ed. Berlin Heidelberg: Springer; 2006. p. 453-89. 